\title{
Business Performance of SMEs in Vidharbha and Khandesh Region of India: A TQM Implementation
}

\author{
S. D. Kalpande (Corresponding author) \\ Mechanical Engineering Department, MET's Institute of Engineering \\ Bhujbal Knowledge City, Nashik, Maharashtra, India \\ E-mail: shyamkumark_ioe@bkc.met.edu \\ R. C. Gupta \\ Industrial and Production Engineering Department \\ Shri. G. S. I. T. S., Indore, Madhya Pradesh \\ E-mail: rcgupta@sgsits.ac.in
}

M. D. Dandekar

Industrial and Production Engineering Department

Shri. G. S. I. T. S., Indore, Madhya Pradesh

E-mail: mddandekar@ rediffmail.com

Received: February 26, 20130

doi:10.5296/ber.v3i1.3770
Accepted: March 12, 2010

URL: http://dx.doi.org/10.5296/ber.v3i1.3770

\begin{abstract}
This paper attempts to identify the importance of factors and sub factors for the successful implementation of Total Quality Management (TQM) in Small and Medium Enterprises (SMEs) in Vidarbha and Khandesh region in India. This study first investigates the critical factors and sub-factors that determine the adoption and successful implementation of TQM. Moreover, the evaluation weights are determined using analytic hierarchy process (AHP). The findings advocate that these enterprises would stress the basic TQM factors of organization and "understanding of customer needs (CN)", "common understanding of quality (UQ)" and "use
\end{abstract}


of team process (TP)" are the most important factors. The results suggest a generic hierarchy model for organizations to prioritize the critical factors and formulate strategies for implementing TQM in Vidarbha and Khandesh, as well as other cities and regions in India.

Keywords: Total quality management, Analytic hierarchy process, SMEs

\section{Introduction}

Contemporary transformation of the business environment due to liberalization, privatization and globalization has increased competitive pressure on the SMEs in India. SMEs are facing an entirely new paradigm of competitive threats like major shift in product and process technology; changes in preference from customer segment; increased customer awareness etc. Under the changed circumstances, ability to generate and utilize knowledge is the only way to sustain one self. Technological innovation is a key to survival and growth for small enterprises in India and so technical entrepreneurship plays a pivotal role in the process of industrialization.

According to Vasundhara, (2000), the liberalized policy has posed certain challenges and provided opportunities to the SMEs. The challenges are in the form of increased competition; reduced protection due to lowering of tariffs and market determined rates of interest. On the other hand opportunities have come in the form of access to better technology, availability of raw material and components; impetus to quality, efficiency and opportunity to restructure and diversify.

To survive in this intensely competitive market, strategies need to be reinvented by the entrepreneurs for venture management. Strategic partnership and strategic alliances have become compelling for the entrepreneurs to achieve success in the existing enterprises.

Study reports (Sandesara, 1993; Chadha, 1995) shows that in India numbers of SMEs are increasing every year. In spite of this, it is also observed that many SMEs are sick and some are close down. It is felt that, the main problem of those SMEs were the low quality of their product and rise in competition in the market. To overcome this situation, SMEs need to adopt a policy of meeting needs of customer through continuous improvements. It is expected that the policy and practice of TQM would help in achieving this.

In spite of various success stories of quality management, still the concept of TQM has not been really adopted by SMEs working in the developing countries (Deshmukh and Lakhe, 2010). The key reason for not appropriate use of TQM in SMEs are, lack of sources and information on TQM, specially oriented to SMEs, lower level of awareness and understanding and cost constraints (Wilkson, 1994; Taylor, 1996).

Literature shows that, SMEs have enjoying the benefits by implementing TQM (Ahir and Gollar, 1999, Lewis, et al., 2005). Kalpande et al., (2012) has focused on framework or TQM model suitable for SMEs working in the industrially week regions. He has also focused on the identified attributes suitable for such SMEs. According to Deshmukh and Lakhe, (2010) the $67.5 \%$ SMEs of central Indian manufacturing industries are aware of the quality tools like six sigma, but very low use of these tools are found in their respective organizations. Goblell and 
Shea, (1995) survey report found that stated reasons for espousing TQM in SMEs are support of growth, (TQM as a marketing tool) changing expectations of customer, improving poor company performance and consistent with management style. Ahir and Goller, (1999) concluded that TQM implementation in SMEs 'represents a good strategy to execute quality management practice in an integrated manner'.

Total quality management (TQM) is often regarded as a philosophy that aims to achieve customer satisfaction through continuous improvement and teamwork. The transformation towards TQM is coupled with its spread, from the manufacturing to the service sector, large scale industries to the small and medium scale industries (Chin, et al., 2002). Implementation of TQM becomes a top management agenda in many organizations in the pursuit of positive business benefits, such as better product quality, higher customer satisfaction and less quality costs. There have been several approaches and models suggested for the TQM introduction and implementation (Tan, 1997). Study report found that many organizations launched TQM programs have gained positive results (Hua, et al., 2000; Pun, 2001).

This paper presents the main findings of a recent study that investigated the critical success factors affecting the implementation of TQM in organizations in central India with particular reference to the manufacturing sector's SMEs in Vidarbha and Khandesh. The Vidarbha and Khandesh region is industrially backward region of the state. The manufacturing industries of Vidarbha region had undergone fast pace economic developments with significant efforts of the social economic zone (www.sezindia.nic.in). This study considers the components of TQM model suitable for SMEs, which are working in the industrially backward region. The author studied manufacturing SMEs in Vidarbha and Khandesh region of Maharashtra state in India. The data is collected through the structured questionnaire. The data is analyzed by Pairwise Comparison Method (PCM). The AHP tool is used to prioritize the identified critical factors and sub-factors. It formulates the strategies for TQM implementation in studied region in context of Indian SMEs.

\section{Critical Factors of TQM Implementation}

The organizational requirement for successful implementation of TQM is through the identification of critical success factors (CSF). To establish empirically validated factors that influence successful implementation of TQM. It needs to be a totally integrated, continuous and open system based on the commitment from top management and employees, as well as the communication with customers (Chin et al., 2000; Tan, 1997). Saraph et al., (1989) proposed measures of overall organizational quality management for both manufacturing and service firms and identified 120 organizational requirements (prescriptions) or effective quality management. Through a judgmental process of grouping similar requirements, these prescriptions were grouped into eight separate categories. These eight categories reflected the prescription of all or nearly all of the quality gurus. The Indian organization's study produced a few conclusions contradictory to widely accepted knowledge, notably that top management direct commitment and hands on involvement are not essential for effective quality performance. An exhaustive list of critical factors consolidated from literature review on TQM implementation is depicted in Table 1. For facilitating discussions, they are divided into Eight 
categories of factors or elements, namely, Use of team process (TP), Focus an internal customers (FI), Common understanding of quality as satisfying the needs of external customers (UQ), Emphasis on the use of data and understanding of variation in decision making (UD), Understanding of customer Needs (CN), Supplier Partnership (SP), Understanding of the organizational process (OP), Understanding of the tech. of Improvements (TI). Each category of factors has several sub-factors as elaborated later.

Table: 1 Critical factors and sub-factors of TQM implementation

\begin{tabular}{|c|c|c|c|c|c|c|c|c|}
\hline Factor & $\begin{array}{l}\text { Use of team } \\
\text { process (TP) }\end{array}$ & $\begin{array}{l}\text { Focus an interral } \\
\text { customers (FI) }\end{array}$ & $\begin{array}{l}\text { Emphasis on the } \\
\text { use of data (UD) }\end{array}$ & $\begin{array}{l}\text { Common } \\
\text { understanding of } \\
\text { quality (UQ) }\end{array}$ & $\begin{array}{l}\text { Understanding of } \\
\text { customer Needs } \\
\text { (CN) }\end{array}$ & $\begin{array}{l}\text { Supplier } \\
\text { Partnership } \\
\text { (SP) }\end{array}$ & $\begin{array}{l}\text { Understanding } \\
\text { of the } \\
\text { organizational } \\
\text { process (OP) }\end{array}$ & $\begin{array}{l}\text { Understanding } \\
\text { of the } \\
\text { techniques of } \\
\text { Improvements } \\
\text { (TD) }\end{array}$ \\
\hline \multirow[t]{3}{*}{$\begin{array}{l}\text { Sub- } \\
\text { factor }\end{array}$} & $\begin{array}{l}\text { Number of } \\
\text { team } \\
\text { activities } \\
\text { (NT) }\end{array}$ & $\begin{array}{l}\text { Staff aware of the } \\
\text { concept of internal } \\
\text { customer } \\
\text { (C I) }\end{array}$ & $\begin{array}{l}\text { Employees } \\
\text { trained in use of } \\
\text { data } \\
\text { (ED) }\end{array}$ & $\begin{array}{l}\text { Staff, aware of the } \\
\text { concept of quality } \\
\text { (CQ) }\end{array}$ & $\begin{array}{l}\text { Ability to express } \\
\text { customer needs } \\
\text { (EC) }\end{array}$ & $\begin{array}{l}\text { Help } \\
\text { renders to } \\
\text { suppliers } \\
\text { (HS) }\end{array}$ & $\begin{array}{l}\text { Processes } \\
\text { documented } \\
\text { (PD) }\end{array}$ & $\begin{array}{l}\text { Application of } \\
\text { various } \\
\text { techniques } \\
\text { (AT) }\end{array}$ \\
\hline & $\begin{array}{l}\text { Effectiveness } \\
\text { of team } \\
\text { process } \\
\text { (ET) }\end{array}$ & $\begin{array}{l}\text { Quality service } \\
\text { received from } \\
\text { intemal supplier } \\
\text { (QD) }\end{array}$ & $\begin{array}{l}\text { Application of } \\
\text { data } \\
(\mathrm{AD})\end{array}$ & $\begin{array}{l}\text { Understand and } \\
\text { express customers' } \\
\text { needs } \\
\text { (UC) }\end{array}$ & $\begin{array}{l}\text { Budget spent on } \\
\text { identifying } \\
\text { customer needs } \\
\text { (BC) }\end{array}$ & $\begin{array}{l}\text { Suppliers } \\
\text { continued } \\
\text { (SC) }\end{array}$ & $\begin{array}{l}\text { Awareness } \\
\text { about the } \\
\text { organizational } \\
\text { process and } \\
\text { documentation } \\
\text { (AP) }\end{array}$ & $\begin{array}{l}\text { Training in Use } \\
\text { of Various } \\
\text { techniques } \\
\text { (TT) }\end{array}$ \\
\hline & $\begin{array}{l}\text { Outcomes of } \\
\text { team } \\
\text { activities } \\
\text { (OT) }\end{array}$ & $\begin{array}{l}\text { Awareness } \\
\text { programs } \\
\text { conducted for } \\
\text { intemal customer } \\
\text { (AI) }\end{array}$ & $\begin{array}{l}\text { Evidence of } \\
\text { impact of } \\
\text { variation on } \\
\text { decision made } \\
\text { (ID) }\end{array}$ & $\begin{array}{l}\text { Trairing programs } \\
\text { conducted for } \\
\text { understanding of } \\
\text { quality } \\
\text { (TQ) }\end{array}$ & $\begin{array}{l}\text { Training programs } \\
\text { conducted to } \\
\text { understanding of } \\
\text { customer Needs } \\
\text { (TC) }\end{array}$ & $\begin{array}{l}\text { Serrinar } \\
\text { organized } \\
\text { (SO) }\end{array}$ & $\begin{array}{l}\text { Undocumented } \\
\text { features of the } \\
\text { processes } \\
\text { (UF) }\end{array}$ & $\begin{array}{l}\text { Staff trained for } \\
\text { New techniques } \\
\text { (ST) }\end{array}$ \\
\hline
\end{tabular}

\subsection{Team Processes}

A team is a group of individual each with specific skills and knowledge of interests that permit the member to contribute to the achievement of common purpose. Number of team registered, number of problem solved to number of problem undertaken and net saving in rupees by implementing the improved method suggested by team, can be considered as indicators to measure the performance of team activities (Crosby, 1979; Deming, 1982; 1986; Ishikawa, 1985; Juran and Gryna, 1988; Feigenbaum, 1991). Being its sub factor i.e. number of team activities (NT), perceived effectiveness of team process (ET) and outcomes of team activities (OT) is as an essential element for achieving TQM implementation.

\subsection{Internal Customer Focus}

Each employee/department is a customer for output from another employee/department and in turn has a customer to whom he provides output. This concept shows that the quality becomes an individual responsibility. Percentage of staff aware about the concept of internal customer (CI), the service received from internal supplier and percentage of staff satisfied with the quality service (QI), average no. of awareness programmes conducted for internal customer (AI) are considered to measuring the components focus on in-house customer (Juran and Gryna, 1988). These functions are as a vehicle to integrate quality requirements with business 
activities of organization.

\subsection{Use of Data}

Quality information programs utilize the data as a fundamental factor in the organization and the company information system which using the information to the measurement and the control of the important areas that impact quality control permanent remedial action (Feingenbaum, 1991). Total percentage of staff trained in use of data (ED), number of case in which the data is used for analysis and decision making i.e. application of data (AD), no of evidences where the past decisions are alerted due to the use of data i.e. impact of deviation on decision made (ID), can be used as a indicator for mapping the emphasis on the use of data (Crosby, 1979; Deming, 1982, 1986; Ishikawa, 1985; Juran and Gryna, 1996;).

\subsection{Common Understanding Of Quality}

Quality awareness also be improved by involving all employees to enables company to make products of quality which could complete successfully in the market-place. The need is to extend training in quality related matter to personnel in all function (Juran and Gryna, 1988). Percentage of staff, aware of the concept of quality (CQ), ability to understand and express customers' needs (UC) and average no of training programmes conducted to improve quality awareness (TQ) are considered as a indicators for measuring quality awareness among employees (Feingenbaum, 1991).

\subsection{Understanding Customer Need}

The needs of all customers have to be met, and the product / service features should be responsive to those needs. This applies to both external and internal customers. In this case of external customers, product salability and in case of internal customers, the response determines the company's competitiveness in productivity, quality etc. as well as the state of morale among internal departments. To measure this concepts, three measures are used i.e. percentage ability to express customer needs (EC) in terms of international activities (specification); percentage of budget spent on identifying customer needs (BC); and average no. of training programmes conducted (TC) to know customer needs (Feingenbaum, 1991).

\subsection{Supplier Partnership}

The secure quality improvement, it is very necessary to achieve teamwork relationship with suppliers. To understand the standing of relationship with the supplies, the three measures can be used (Juran and Gryna, 1988; Feingenbaum, 1991).

a. Financial and technical help renders to suppliers (HS) in terms of rupees;

b. Numbers of suppliers continued (SC) in last three years; and

c. Average number of seminar organized (SO),

\subsection{Understanding Organization Processes}

Documentation is an important tool to understand the organization process. The major two reasons shows the importance of appropriate documentation, first to achieve the company's 
objectives related to quality and its evaluation by audits and management review to create and maintain a continuous improvement. For measuring these components, the number of measures are used which includes, percentage of total number of processes documented (PD); the percentage of employees awareness about the organizational process as well as documentation (AP) and percentage clarity of the undocumented aspects/features of the processes (UF).

\subsection{Quality Improvements Techniques}

Number of improvement techniques used; organization of number of training programs to educate the staff, in use of various numbers of technique of improvement and total percentage of staff trained may be used as an indicator to know the understanding of techniques of development (Crosby, 1979). The techniques for improvement are grouped in four categories, which are- Management methods (PDCA, DDA- Departmental purpose analysis, cost-benefit analysis, Poka-yoke, Potential problem analysis, Benchmarking, QFD- (Quality function deployment), Pareto analysis, Analytical and systematic methods (critical path analysis (CPA), cause and effect diagram, failure mode and effect analysis, fault tree analysis, Tolerance design and Taguchi method etc.), Idea Generation (idea writing, opportunity analysis, buzz group, brainstorming, lateral thinking ) and Data collection and analysis with display ( bar chart, 'P' chart, check sheet, flow chart, scatter diagram, histograms etc.). The sub factor i.e. application of number of techniques. (AT), Training in Use of a variety of techniques (TT), and Percentage of Staff trained (ST) helps organization to evaluate the achievements and monitor continuous improvement efforts moving to the right direction.

\section{Research Methodologies}

TQM implementation is becoming a complicated practice as the number of factors and elements affecting it increase. The AHP devised by Saaty (1996) is a powerful technique in solving fuzzy and complex decision problems. The process can be used to make trade-off and determine priorities among factors and sub-factors that are critical to making sound decisions with TQM implementation. On this background, for assessing the TQM orientation in SMEs, a questionnaire was developed on the objective of to indentify criteria's and quantifiable indicators for measuring the components of TQM model and develop a multi-attributes decision model (Analytic Hierarchy Process-AHP). This objective could measure the progress of a unit towards the TQM philosophy.

In order to investigate the managerial views on the critical factors that will affect the implementation of TQM. The data is collected through the structured questionnaire from the SMEs of Vidarbha and Khandesh region in the field of manufacturing. It sought answers to develop the weight criteria of TQM components for proposed TQM model. The AHP tool is used for development of TQM implementation model which uses and explicit the weightage system of its components by pairwise comparison method. The paired comparison method was adopted as it is simple to administer to a generalist target group and provides reasonable confidence. The relative weights or priorities were obtained by taking the opinion of sixteen experts from the field of quality management. The study has gone through three phases, including: 
(1) Structuring the problem and building the AHP model;

(2) Collecting data from expert interviews; and

(3) Determining the normalized priority weights of individual factors and sub-factors.

Phase 1: Structuring a hierarchy model for TQM implementation

Considering the TQM framework advocated by Dale and Boaden (1993) and the critical factors consolidated from literature, the problem of TQM implementation was decomposed into a model of hierarchical structure. The model has four levels, in Level 1 states the goal of the problem (i.e. to decide whether implement TQM). Level 2 consists of the critical factors, and Level 3 lists the sub-factors of individual critical factors as shown in Table 1. Level 4 is the desired results of the TQM implementation.

\section{Phase 2: Measuring and collecting data}

The data is evaluated by the selected experts in the field of quality management. The experts were selected without affecting their uniformity. The evaluations of data were carried by comparing the elements with each other by pairwise comparison method. The AHP converts these evaluations to numerical values that can be processed and compared over the entire range of the problem. A numerical weight or priority is derived for each element of the hierarchy, allowing diverse and often incommensurable elements to be compared to one another in a rational and consistent way. This capability distinguishes the AHP from other decision making techniques. Saaty's point scale was employed to assign relative scores to pair-wise comparisons amongst the factors and sub-factors (Saaty, 2008).

\section{Phase 3: Determining the normalized weights}

In order to determine the relative importance of the factors and sub-factors, those judgment matrices were translated into decision matrix. The resulting priority weights determined the relative importance of individual factors and sub-factors, and in turn identified the points on which organizations should put their efforts throughout the process of TQM implementation. As the results are not dependent on perfect consistency (random judgment), this rarely exists in practice. Saaty (2008) suggested that a consistency ratio (CR) less than 0.10 or $10 \%$ is considered adequate. The consistency ratio is used as the main indicator of ranking consistency.

\section{Results Analysis and Discussion}

The SMEs of industrially backward region of India has involved in this study. To clarify importance of the critical factors and sub-factors for implementing TQM, the judgments collected from evaluators generated the normalized local and global weights for the factors and sub-factors. The results could reflect the general status of TQM implementation in Vidarbha and Khandesh region manufacturing SMEs. The study had generated weightage of attributes calculated from the response of each enterprises representative. The random consistency checked by calculating the critical ratio (CR). All CR is less than 0.10 or $10 \%$ is considered adequate. If CR more than 0.1 or $10 \%$ the inconsistency of judgments within that matrix has 
occurred and the evaluation process should therefore be reviewed, reconsidered and improved (Saaty, 2008).

The result analysis shows that the attribute $\mathrm{CN}$ was the most critical factor with highest normalized local weight of 0.3546 in the second hierarchy level. The subsequent important attributes are UQ and TP with the normalized local weight of 0.2218 and 0.1498 respectively. The CN, UQ and TP factors were significantly affecting the decisions regarding TQM implementation. On the other hand, SP, TI, UD, FI and OP were regarded as the supporting factor for implementation of TQM in the studied organizations.

In third hierarchy level, ET, EC and UC was the most important, and NT, BC, and TQ was the least important sub factor and the weight of SC, UF, ED and AI has received least importance.

As the sample size $(n)$ is of sixteen SMEs i.e. less than 30, means $n<30$, the distribution of $t$ has useful to deal with the exact, distribution of $t$ assuming that random sample was selected from a normal population (Walpole, et al., 2007).

Critical values of $t$-distribution denoted by $t_{\alpha}$ which shows the area under the curve to the right of $t_{\alpha}$ equals to $\alpha$ (See Figure 1). For the $99 \%$ confidence level with studied sample size ' $n$ ', the distribution of $t$ statistic from $(n-1)$ degree of freedom. As the all the $t$ - calculated values of mean of attribute are less than given value so the process is under control also. i.e. $t_{c a l}<t_{\alpha}$, So the process is under control.

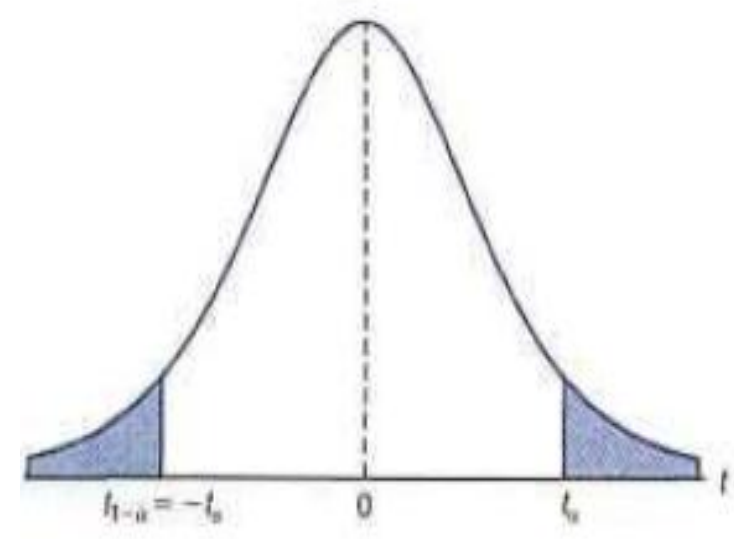

Figure 1 . Symmetry property of the t-distribution

Based on the studied sample, the results show that the understanding of customer need, quality and team process would have greater governance on the effective TQM implementation than that of the supplier's partnership, technical improvements and use of data. To create the industrial culture through the basic components of TQM has a need rather than to upgrade the existing quality methodologies in industrially backward region like Vidarbha and Khandesh. The findings affirmed the argument that TQM was a kind of management philosophy rather than a technique. It helps organizations for to identify their strengths to drive towards continuous improvement. In addition, the evaluators' rankings of critical factors also provided good insights of their deviated focuses on the TQM implementation. 


\section{$\Lambda$ Macrothink}

\section{Conclusion}

Implementation of TQM requires thorough organizational transformation, especially in the areas of operation mode, organization structure and corporate culture. The complexity and difficulty of TQM implementation predestinate organizing to be the most fundamental and important factor. To understand the customer need was the most important factors found in this study. In addition, establishment of harmonious and participative organization culture will not only facilitate TQM implementation, but also facilitate the long-term development of enterprises. The study findings suggest that the hard factors (e.g. quality systems, performance measurement, communication, and quality improvement techniques or methods) are an indispensable part of TQM implementation. However, it is impossible for the hard factors to bring on high quality alone as their effectiveness would rely significantly on the support from the soft factors of TQM implementation, and more importantly, the people who utilize them.

The study shows that CN, UQ and TP are the major issues for the SMEs of this region due to low industrial development, lack quality consciousness, under utilization of capacity, non availability of trained workers, high absenteeism of worker and lack of work culture. Besides many reasons, few important reasons are 'Lack of knowledge of TQM' and 'TQM adoption philosophy for continuous improvement'. This AHP approach helps organization for identification of the thrust areas and develops the strategies for the TQM implementation. In addition, the company can also use the assessment results as a benchmark with competitors and other 'best-in-class' organizations.

\section{References}

Ahir, S. \& Goller, G. (1999). Quality management in large Vs small businesses, Journal of Small Business Management, 34(2), 1-13.

Chadha, V. (1995). Technological modernization of small sector in India, Productivity, 36(3). 463-469.

Chin, K. S., Dale, B. G., \& Pun, K. F. (2000). Implementing the UMIST Total Quality Management Framework in Hong Kong Manufacturing Industries. City University Press, Hong Kong.

Chin, K. S., Pun, K. F., Xu, Y., \& Chan, J. S. F. (2002). An AHP Based Study of critical factors for TQM implementation in Shanghai manufacturing industries, Technovation, 22, 707-715. http://dx.doi.org/10.1016/S0166-4972(01)00065-7

Crosby, P. B. (1979). Quality is Free: The Art of Making Quality Certain, Penguin Books, New York.

Dale, B. G. \& Boaden, R. J. (1993). Improvement framework, TQM Magazine, 5(1), 23-26. http://dx.doi.org/10.1108/eb059544

Deming, W. E. (1982). Quality, Productivity and Competitive Position, MIT Center for Advance Engineering, Cambridge, MA.

Deming, W. E. (1986). Out of the Crisis. MIT Centre for Advanced Engineering Study 


\section{MInstitute ${ }_{\text {Mnk }}^{\text {Macrothin }}$}

Business and Economic Research ISSN 2162-4860

Cambridge, MA.

Deshmukh, S. V. \& Lakhe, R. R. (2010). Six Sigma awareness in central Indian SMEs, International Journal of Productivity and Quality Management, 5(2), 200-212. http://dx.doi.org/10.1504/IJPQM.2010.030742

Feingenbaum, A. V. (1991). Total Quality Control, McGraw Hill, New York.

Goblell, D. \& Shea, J. (1995). TQM: The experience of 10 small businesses, Business Horizons, $2,125-135$.

Hua, H. M., Chin, K. S., Sun, H.Y., \& Xu, Y. (2000). An empirical study on quality management practices in shanghai manufacturing industries, Total Quality Management, 11(8), 1111-1122. http://dx.doi.org/10.1080/095441200440368

Ishikawa, K. (1985). What is Total Quality Control? The Japanese Way, Translated by Lu, DJ, Prentice Hall, Englewood Cliffs, NJ, USA.

Juran, J. M. \& Gryna, F. M. (1988). Juran's quality control- Handbook, McGraw Hill , New York.

Juran, J. M. \& Gryna, F. M. (1996). Quality planning and analysis, Tata McGraw Hill, New Delhi.

Kalpande, S. D., Gupta, R. C. \& Dandekar, M. D. (2012). Framework of TQM implementation in small businesses of an industrially backward region: A concept, Wiley Online Library, Performance Improvement, 51(7), 07-13.

Lewis, W. G., Pun, K. F., \& Lalla, T.R.M. (20050, An AHP based study of TQM benefits in ISO 9001 certified SMEs in Trinidad and Tobago, The TQM Magazine, 17(6), 558-572. http://dx.doi.org/10.1108/09544780510627651

Pun, K. F. (2001). Cultural influences on total quality management adoption in Chinese enterprises: an empirical study, Total Quality Management, 12(3), 323-342. http://dx.doi.org/10.1080/09544120120034483

Saaty, T. L. (1996). Multicriteria Decision Making. R.W.S. Publications, Pittsburgh, PA.

Saaty, T. L. (2008). Relative Measurement and Its Generalization in Decision Making. Why Pairwise Comparisons are Central in Mathematics for the Measurement of Intangible Factors. The Analytic Hierarchy/Network Process, RACSAM, Rev. R. Acad, Cien, Serie A. Mat., 102(2), 257.

Sandesara, J. C. (1993). Industrial policy and planning, Sage publication, New Delhi, India.

Saraph, J. V., Benson, P. G., \& Schroeder, R. C. (1989). An instrument for measuring the critical factors of TQM, Decision Sciences, 20, 810-829. http://dx.doi.org/10.1111/j.1540-5915.1989.tb01421.x

Tan, P. K. L. (1997). An evaluation of TQM and the techniques for successful implementation, Training for Quality, 5(4), 150-159. http://dx.doi.org/10.1108/09684879710188158 


\section{Macrothink}

Business and Economic Research

ISSN 2162-4860

2013, Vol. 3, No. 1

Taylor, W. A. (1996). Sectional differences in total quality management implementation: the influence of management mindset, TQM, 7(3), 22-28.

Vasundhara, R. (2000). Taking SSI towards new millennium- Message of Hope, Laghu- Udyog, Vol. 24-25, Apr.-Sept, pp. 1-5.

Walpole, R. E., Myers, R. H., Myers, S. L. \& Ye, K. (2007). Probability \& Statistics for Engineers \& Scientists (8 ${ }^{\text {th }}$ Ed)., Pearson Prentice Hall, NJ, ISBN 0 - 13 - 204767 -5.

Wilkson, A. (1994). The problems with quality management, TQM Magazine, 5(6), 102-109. www.sezindia.nic.in.

\section{Copyright Disclaimer}

Copyright reserved by the author(s).

This article is an open-access article distributed under the terms and conditions of the Creative Commons Attribution license (http://creativecommons.org/licenses/by/3.0/). 